\title{
Integrated GIS and Remote Sensing for Runoff Hazard Analysis in Ain Sukhna Industrial Area, Egypt
}

\author{
M. G. El-Behiry, A. Shedid*, \\ A. Abu-Khadra** and M. El-Huseiny* \\ Geophysics Department, Faculty of Earth Sciences, \\ King Abdulaziz University, Jeddah, Saudi Arabia, \\ e-mail:malbehiri@kau.edu.sa, \\ *Geology Department, Faculty of Science, Fayoum University, Fayoum, and \\ **Geology Department, Faculty of Science, Cairo University, Giza, Egypt
}

Received: 07/05/2005

Accepted: 14/12/2005

\begin{abstract}
Delineating drainage networks is essential to predict surface water runoff, and consequently the flash flood hazards. Quantitative description of drainage basin and drainage network is confronted with problems related to the scale and resolution of the used topographic maps, and to the implemented systematic interpretation method. Integrated Geographic Information Systems (GIS), and remote sensing data overlaid on large-scale topographic maps, can efficiently be used to study the prevailed drainage network, and hence surface water potentiality. The developed integrated approach is applied for quantitative analysis of geomorphometeric parameters, and to delineate the watershed of Wadi Ghoweibba basin in Ain Sukhna area, western side of the Gulf of Suez, Egypt. Quantitative analysis of geomorphometeric parameters calculated for Wadi Ghoweibba basin is used to decipher the flash flood risk zones and to establish an effective hazard mitigation scheme.
\end{abstract}

\section{Introduction}

Delineation of drainage basins and flash flood hazard studies have been achieved by many workers in different areas in Egypt (El-Rakaiby, 1989; Hassan, 1997 and El-Fakharany, 1998). Most of the final output of these studies have shown lack of accuracy due to scale effect of implemented topographic sheets and the used traditional interpretation methods. 
Geographic information systems (GIS) and Remote Sensing through satellite images are new developments that give the opportunity to investigate large areas in a short time. Satellite images can give detailed information on surface geology, soils, vegetation, land use; landscape and can show structures and patterns that would be non recognizable from ground. These features can reveal important information that can lead not only to discover new resources, but also gives a better insight in the current resources used and the development options (Sabins, 2000). The integration between GIS and Remote Sensing techniques is used in the present work essentially to study the drainage network and surface water potentiality in order to evaluate the degree of feeding to the groundwater aquifer in Ain Sukhna area, Egypt.

Two main problems confront the quantitative description of drainage basin and the drainage network to predict runoff. The first problem is the time consuming to interpret the drainage network from topographic maps in order to compute the drainage parameters. The second problem is related to the scale and resolution of the used maps and to the systematic method used to interpret the basin network. For these reasons, values of geomorphometric parameters calculated from different sources or interpreted by different investigators for the same basin may be significantly different. This in fact made difficult to develop a meaningful database of morphometric parameters (Ashour \& Torab, 1991 and Abdel Moneim et al., 1999).

In the present study, the watershed of Wadi Ghoweibba basin in Ain Sukhna area, Egypt, would be delineated for quantitative geomorphometric analysis. The influences of scale effect on the outputs as well as the use of remote sensing technique in terms of satellite images to enhance the accuracy of these outputs are discussed. The problems facing the automation of drainage network directly from GIS technique are also highlighted. Finally, geomorphometric analysis are used to delineate the flash flood risk zones and to setup methods of hazards mitigation.

\section{Location and Geologic Setting}

Ain Sukhna industrial area lies between long. 31 $38^{\prime} 14^{\prime \prime}$ and $32^{\circ} 21^{\prime} 53^{\prime \prime}$ East, and lat. $29^{\circ} 10^{\prime} 56^{\prime \prime}$ and $29^{\circ} 53^{\prime} 44^{\prime \prime}$ North (Fig. 1). It is located at the western side of the Gulf of Suez, Eastern Desert, Egypt. Wadi Ghoweibba represents one of the largest basins in the Eastern Desert of Egypt. It covers an area of $3043 \mathrm{~km}^{2}$ with $70 \mathrm{~km}$ length and basin perimeter of $298 \mathrm{~km}$. Wadi Ghoweibba is located in the wide depression between the southern scarp of Gebel Ataqa on the north, and the northern scarp of Gebel El-Galala El-Bahariya on the south. The Gulf of Suez bound it from the east, while to the west it rises gradually until it merges into the central plateau forming the northern part of the Eastern Desert (Fig. 1). 


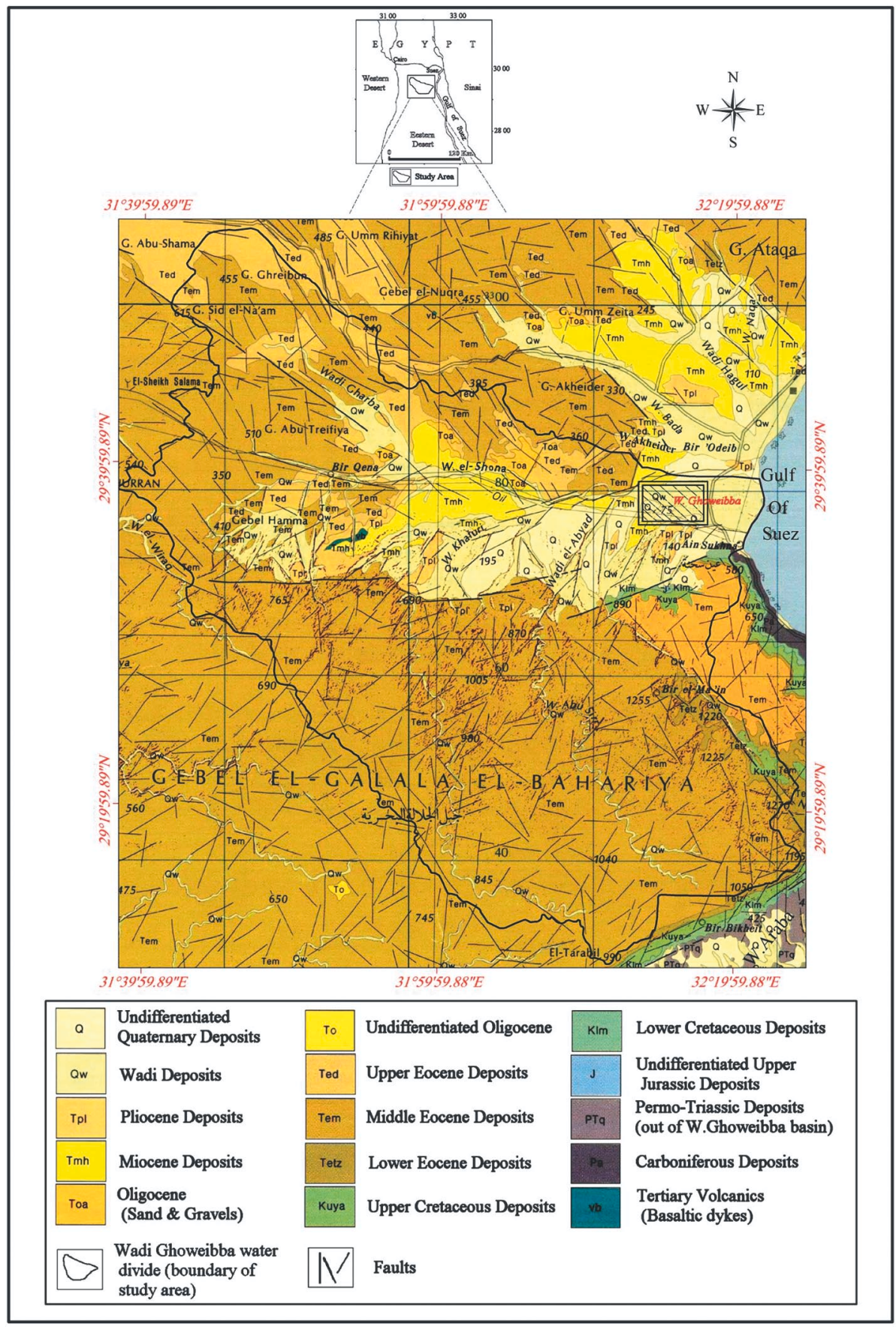

Fig. 1. Geologic map of the study area and its surroundings. (after Conoco, 1987). 
Most of the exposed rocks in the study area are all of sedimentary origin ranging in age from Upper Paleozoic to Recent (Conoco, 1987 and Abdullah, 1993). The Permo-Triassic age is exposed only in the extremely southern part of Wadi Ghoweibba basin. The climatic conditions prevailing in the area are typically arid. The study area, which is a part of the northern Eastern Desert, receives small amounts of rainfall $(25.0 \mathrm{~mm} /$ year) mainly in autumn and winter (ElRakaiby, 1989). Figure (2) shows Wadi Ghoweibba and its tributaries. It shows also the drainage directions of upstream and downstream.

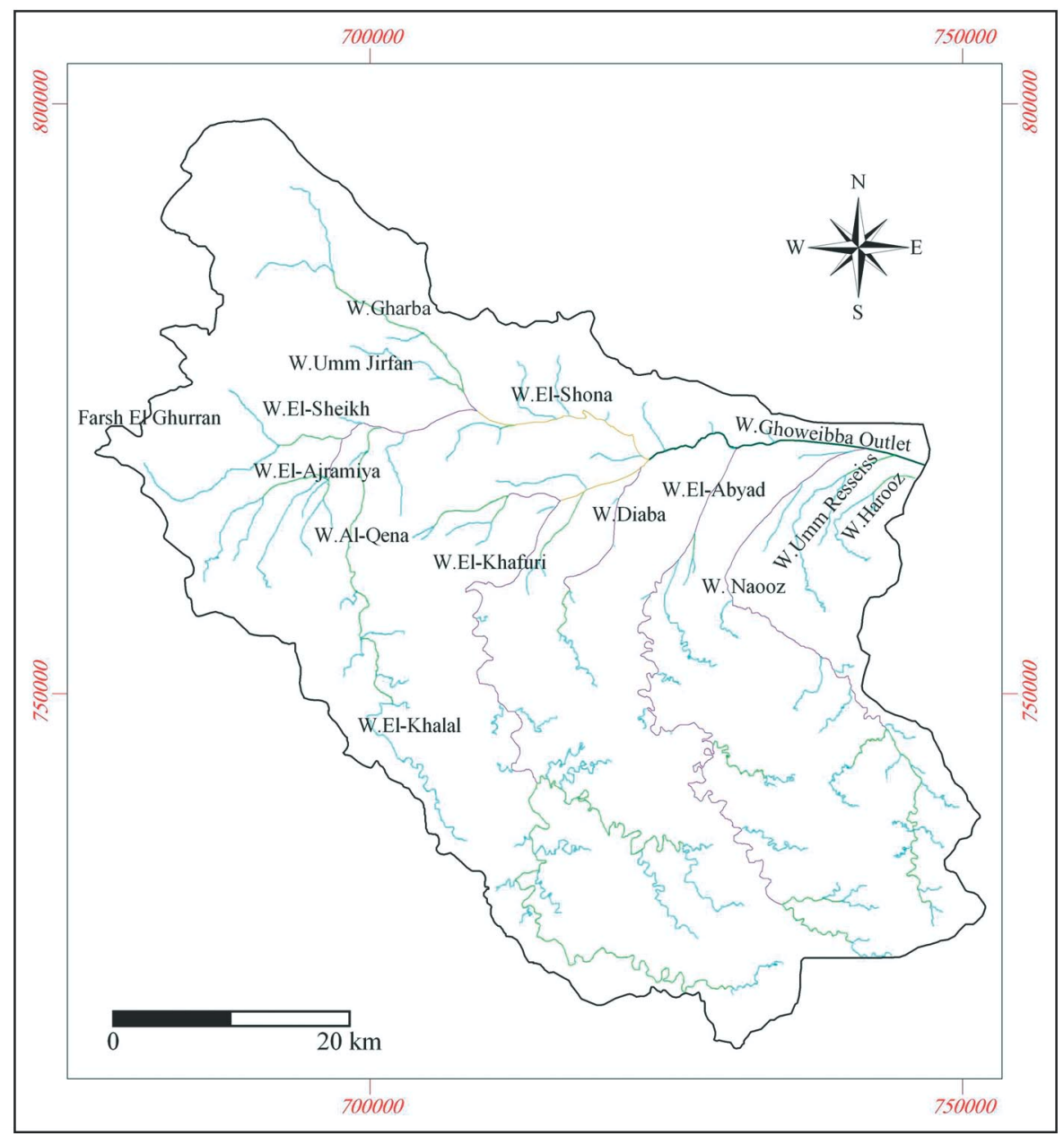

Fig. 2. Wadi Ghoweibba and its tributaries. 


\section{GIS to Automate Drainage Networks}

Geographic information systems (GIS) are computer-based systems for storing, retrieving, manipulating and displaying spatial data (Sabins, 2000). The applications of GIS in hydrology and water resource studies fall into two main categories; informational and analytical. In fact, many steps are required to achieve automated procedure for deriving morphometric basin characteristics using GIS applications. The first step is to create four digital base maps; a drainage-divide map, a basin length map, a drainage network map, and an elevation contour map. The first two maps are created manually by digitizing topographic maps while the third and fourth maps are developed automatically by a raster GIS file called digital elevation model (DEM) containing digital elevation data. The second step uses custom computer software to assign attributes to points, lines and polygons in three of the base maps. The third step is to quantify morphometric basin characteristics including measurements of area, length, shape and relief. Hence, the precipitation data for the flood estimation analysis can be digitally quantified.

GIS-software package (ArcView, V.3.2, (ESRI, 1999)) is used in the present study to create the drainage networks directly from the DEM file. The DEM file is created by first digitize the topographic map (scale 1:50,000) to transfer the topographic lines and the elevation points into digital files. Second, these digitized data are then introduced to the ArcView-software to create the TIN (Triangular Irregular Networks) from which the DEM file is produced.

In the present study, the DEM file contains both contour lines and the spot heights from topographic maps of scale 1:50,000 (Fig. 3). The automated drainage networks of Wadi Ghoweibba created from the available hydrologic data is shown in Fig. 4. We will focus here on Wadi Umm Jirfan (sub-catchments of Wadi Ghoweibba basin and located in the north-west of the basin as shown in Fig. 2) to show the confidence in the hydrologic model. The automated networks revealed great matching in the area of high relief while in the areas of flat terrain (outlets), at the eastern part, show great disturbance in water directions. The comparison between the automated drainage networks derived from the DEM with those networks on the original topographic maps revealed that the interference and disturbance in water directions produced in the automated networks are directly related to DEM output data and not due to errors in the shape or even location of contour lines. It can be observed that, the erroneous DEM zones are always accompanied by areas of large contour spacing due to the flatness of the area and the large contour intervals used in the topographic maps. Stuebe and Johnson (1990) had the same conclusion in a humid environment as they compare between the GIS-generated runoff estimation with the manual runoff calculated in six watershed areas. In such case, we have to delineate the 


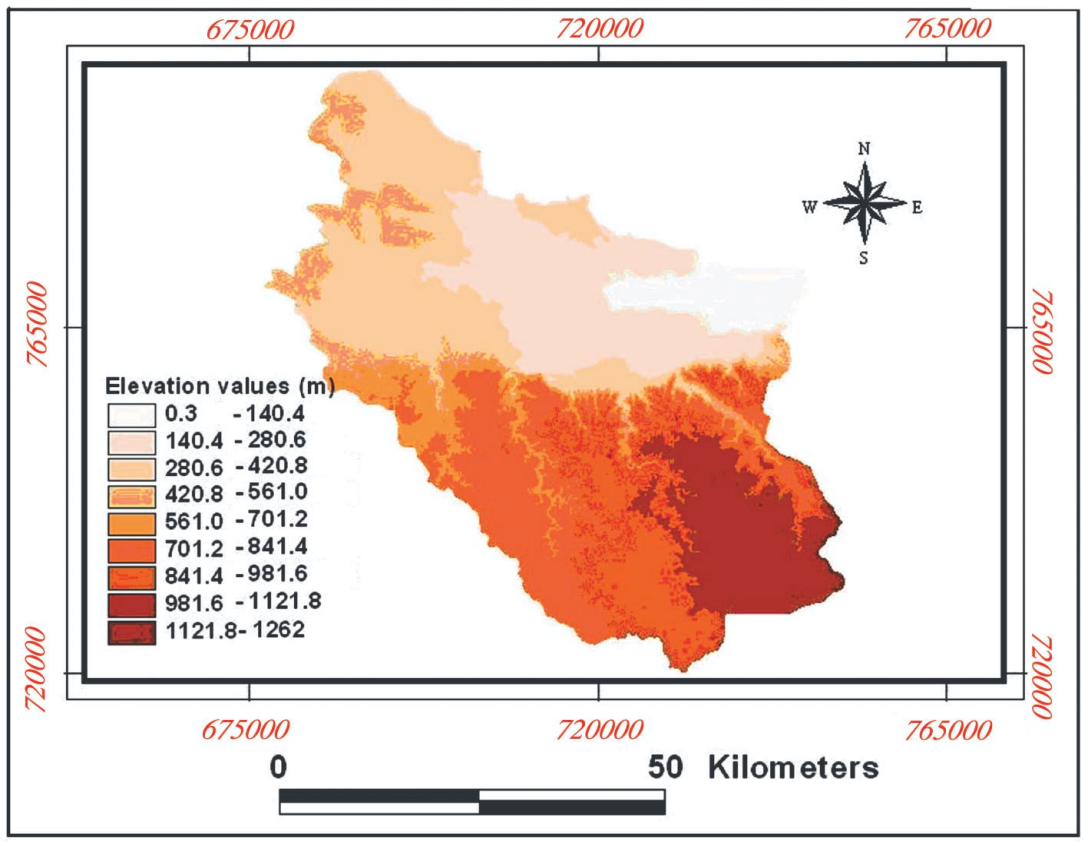

Fig. 3. The digital elevation model (DEM) of the study area.

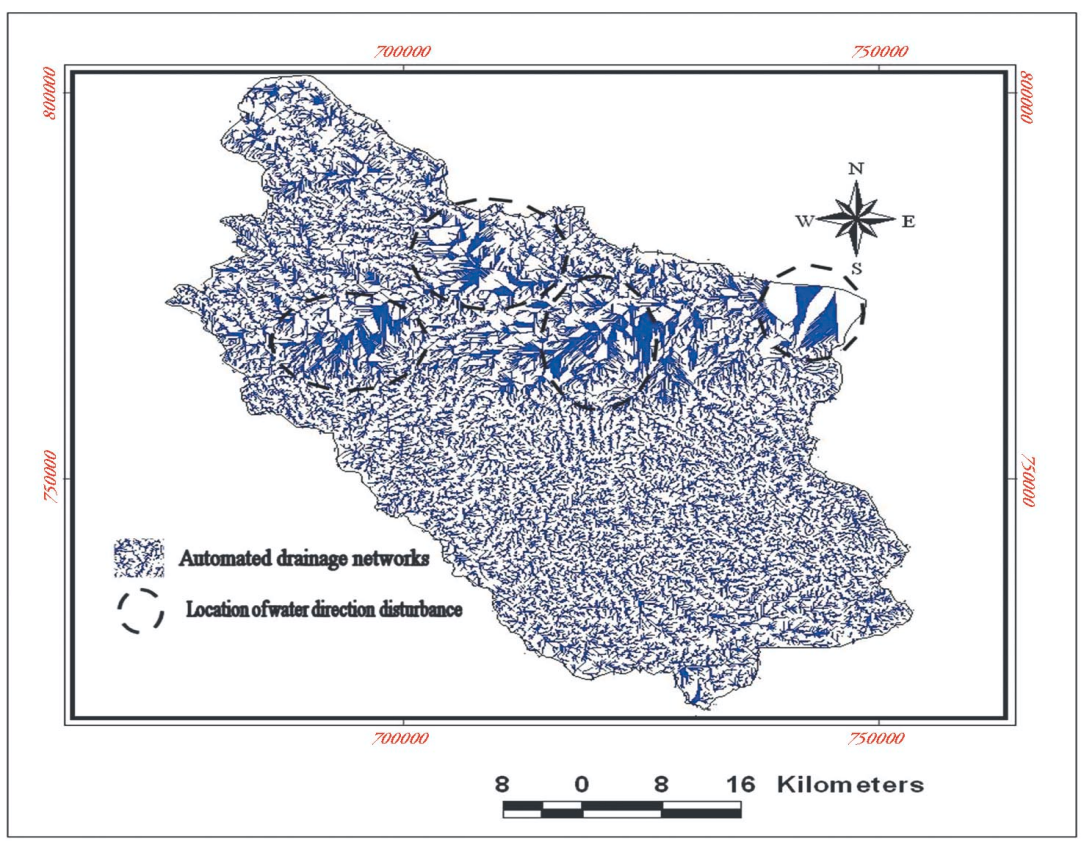

Fig. 4. Automated drainage networks of Wadi Ghoweibba basin. 
drainage networks observed at the available topographic maps of large scales. The dependency of the drainage networks on the scale of topographic maps is a serious pitfall in this procedure.

\section{Scale Effect}

The scale of the topographic maps has much effect on the accuracy of morphometric analysis. It must be emphasized that, the precision of watershed calculations is directly dependent on the scale of topographic maps used. The difference in the scale of topographic maps does not only cause over simplification growth of stream orders, but also causes many changes in the ratios of the lower order streams (Hassaan, 1997). The scale of the topographic maps would be the same in both the horizontal and in the vertical direction. Features that have dimensions less than the horizontal scale of the topographic maps would appear as very fine segments or in some cases would not appear at all. However, the vertical scale used in the topographic maps plays an important role in defining the short streams especially in areas of flat terrains. Streams of first order would not be visible, on area of flat terrains, on the topographic maps with large contour intervals and spacing, and the changes in its shape characteristics within the contour interval would not be detectable. Therefore, the segments (streams) on the topographic maps of scale 1:100,000, for example, which have been considered as first order on these maps, will be classified of second order streams or even third on topographic maps of scale 1:50,000 (Hassaan, 1997). Therefore, the growth in lower order streams and the higher accuracy in watershed analysis are expected in larger scale topographic maps.

In the present study, Wadi Umm Jirfan (Fig. 5) will be examined to illustrate the inherent accuracy between maps with different scales $(1: 100,000$ and 1:50,000) and to emphasize the scale influence on watershed calculations. First, both topographic maps are geo-referenced and referred to one coordinate system. Second, the stream networks are digitized from both topographic maps. Figure $6(\mathrm{a} \& \mathrm{~b})$ show the digitized networks derived from topographic maps of scales 1:100,000 and 1:50,000, respectively. The comparison between the two figures revealed the following:

1. The total number of streams is different. The stream network segments shown in the map with scale 1:50,000 are more than that of scale 1:100,000. The lengths of streams per order are different between the two figures (Table 1). These differences are due to higher resolution revealed by topographic map of the larger scale.

2. The streams order classification is different especially in high orders. The streams of $3^{\text {rd }}$-order in the topo-map of scale 1:50,000 have been classified as streams of $2^{\text {nd }}$-order in the topo-map of scale 1:100,000. Moreover, the main 


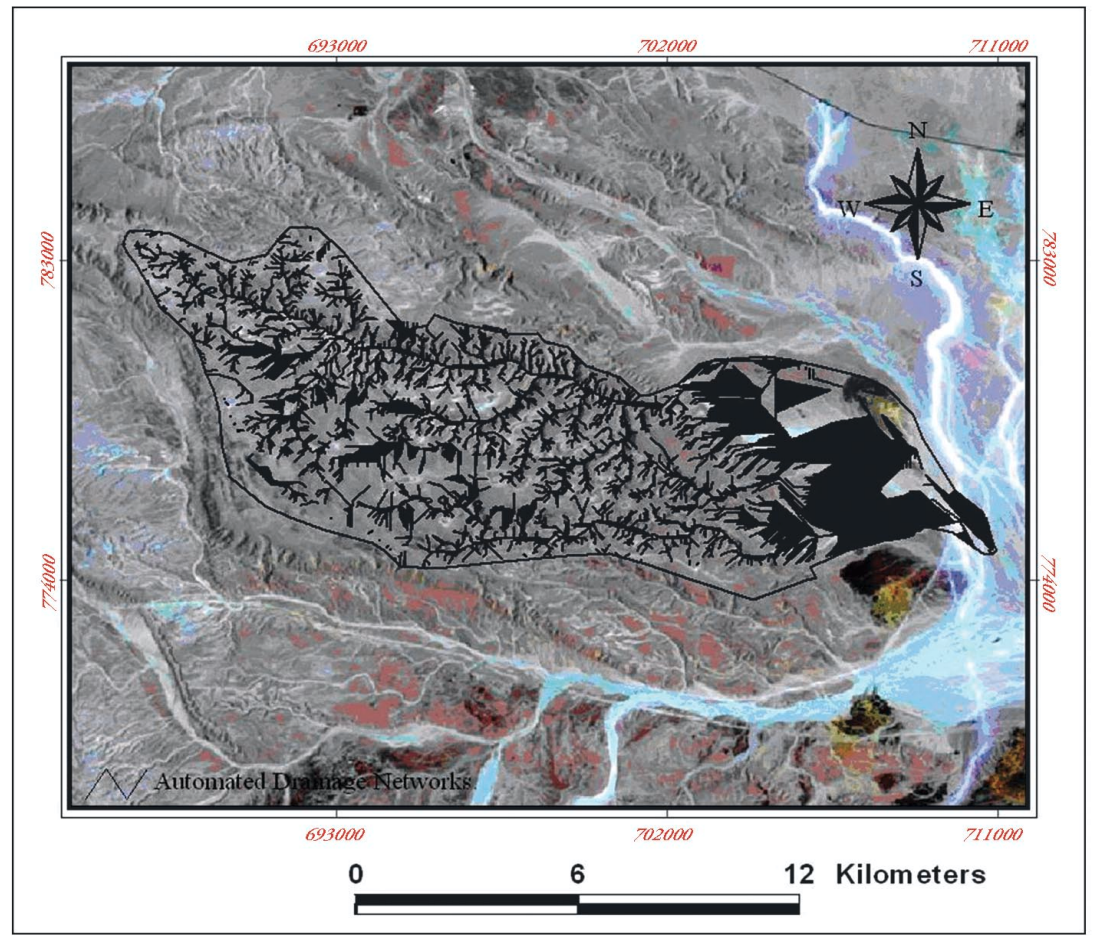

Fig. 5. Automated drainage networks of Wadi Umm Jirfan basin.

Table 1. Some morphometric parameters of Wadi Umm Jirfan as derived from topographic maps of different scales.

\begin{tabular}{|c|c|c|c|c|}
\hline \multirow[b]{2}{*}{ Order } & \multicolumn{2}{|c|}{ Scale 1:100,000 } & \multicolumn{2}{|c|}{ Scale $1: 50,000$} \\
\hline & No. of segments & $\begin{array}{l}\text { Length of segments } \\
(\mathrm{km})\end{array}$ & No. of segments & $\begin{array}{c}\text { Length of segments } \\
(\mathrm{km})\end{array}$ \\
\hline First & 67 & 58.2 & 184 & 126.2 \\
\hline Second & 20 & 26.1 & 42 & 36.2 \\
\hline Third & 5 & 15.1 & 8 & 24.6 \\
\hline Fourth & 1 & 16.3 & 2 & 5.9 \\
\hline Fifth & & & 1 & 11.0 \\
\hline Bifurcation ratio & \multicolumn{2}{|c|}{4.11} & \multicolumn{2}{|c|}{3.9} \\
\hline Stream density & \multicolumn{2}{|c|}{1.6} & \multicolumn{2}{|c|}{2.8} \\
\hline Stream Frequency & \multicolumn{2}{|c|}{1.28} & \multicolumn{2}{|c|}{2.5} \\
\hline Texture ratio & \multicolumn{2}{|c|}{2.08} & \multicolumn{2}{|c|}{5.3} \\
\hline
\end{tabular}

Basin area $=72.38 \mathrm{~km}^{2}$, Basin perimeter $=44.7 \mathrm{~km}$, Stream Density $=\mathrm{km} / \mathrm{km}^{2}$, and Stream Frequency $=\mathrm{N} / \mathrm{km}^{2}$. 
trunk of Wadi Umm Jirfan is classified as $4^{\text {th }}$-order in the topo-map of scale $1: 100,000$ while it was defined as $5^{\text {th }}$-order trunk in the topo-map of scale 1:50,000. The huge amount of low order streams that were digitized in the topographic maps of the large scale explains such differences in the streams orders.

3. The accuracy of the topographic maps depends also on the map production date. In the present work, digitized networks are based on two topographic maps produced in 1953 (Fig. 6a) and in 1997 (Fig. 6b). Shifting in the positions of streams is sometimes being expected. Old topographic maps are based on old collections of data where sometimes trunks could be shifted with time due to desertification effect.

\section{Accuracy Enhancement Using Satellite Image}

Combining the remote sensing data in terms of satellite images with topographic maps of lower scale would noticeably enhance the accuracy of maps outputs. Overlying the digitized networks on satellite images is considered as a good routine to enhance the accuracy of output networks and minimize the errors in the basin calculations. Another advantage of using the satellite images is getting high resolution and updated view of the drainage pattern.

The recent satellite images would record any changes may have happened in the drainage pattern due to the time factor. An area is selected (Fig. 7a) within Umm Jirfan catchment as an example to show the influence of supported satellite image on the networks output. Figure 7(b) shows digitized networks derived from topographic map of scale 1:50,000 overlaid and enhanced using satellite image (LANDSAT TM 5). Many unrecognized segments of stream networks could be observed due to not taking the satellite image into consideration. Figure 7(c) shows the enhanced final networks after on-screen editing and correction from the underlain satellite image. The output of enhanced networks would not be satisfactory if the geo-referencing for both topographic maps and satellite images have not had the same accuracy. The sum of errors in georeference control points for both maps and images should be minimum (Drury, 1993).

Figure 8 shows the final enhanced drainage networks after on-screen editing and correction from satellite image. Differences are obvious in the numbers of both streams and orders between the results derived from topographic maps with and without image enhancement (Tables 1\&2). The differences in output are due to the high resolution revealed by the satellite image. Also, the variations in drainage density, drainage frequency and texture ratio values confirm the influence of map scale on morphometric parameters calculation. 


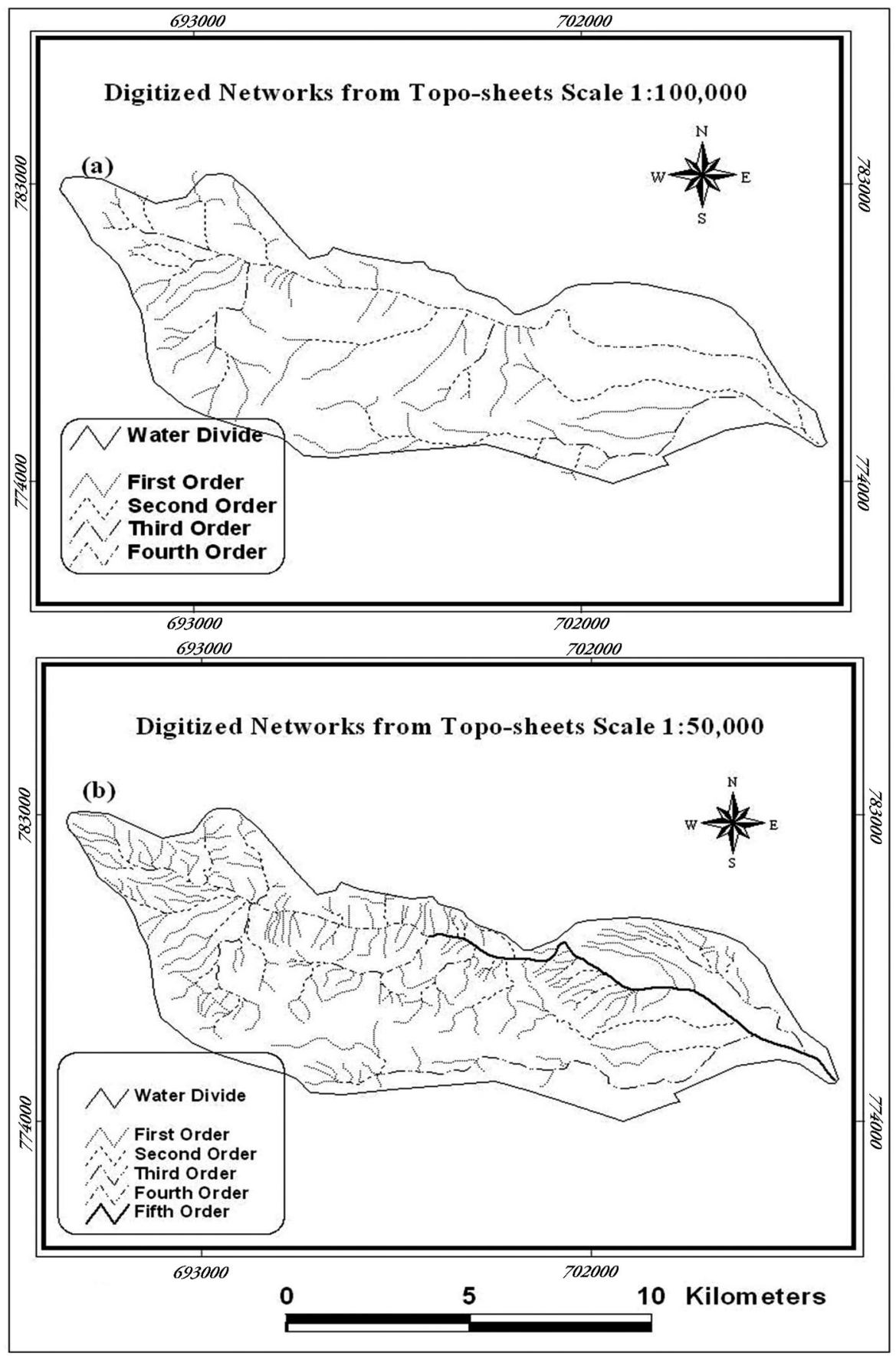

Fig. 6. Scale effect on watershed analysis of Wadi Umm Jirfan basin. 


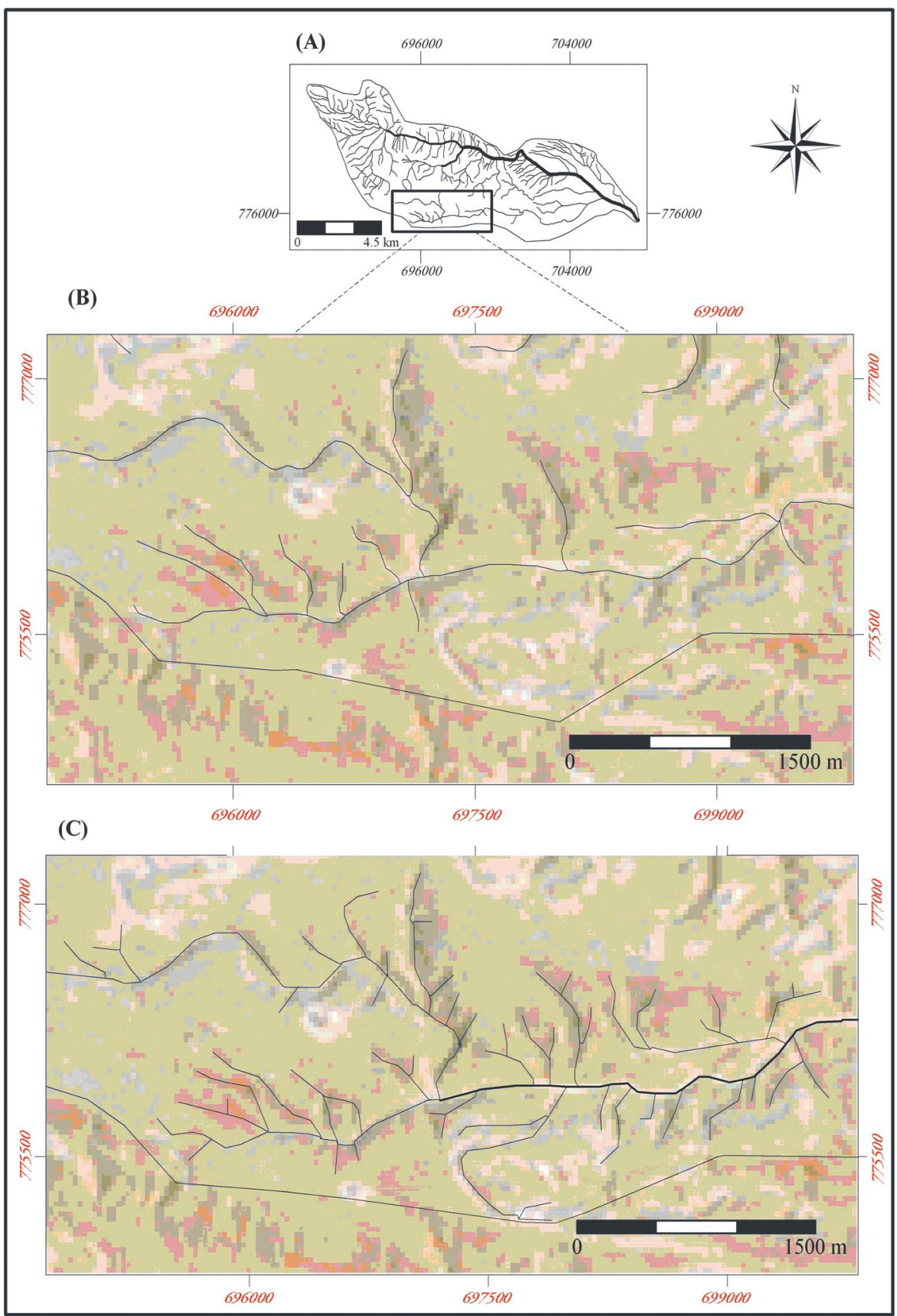

Fig. 7. (A) Wadi Umm Jirfan selected area, (B) digitized networks derived from topographic map of scale 1:50,000 overlaid on satellite image, and (C) enhanced networks after on-screen editing and correction. 


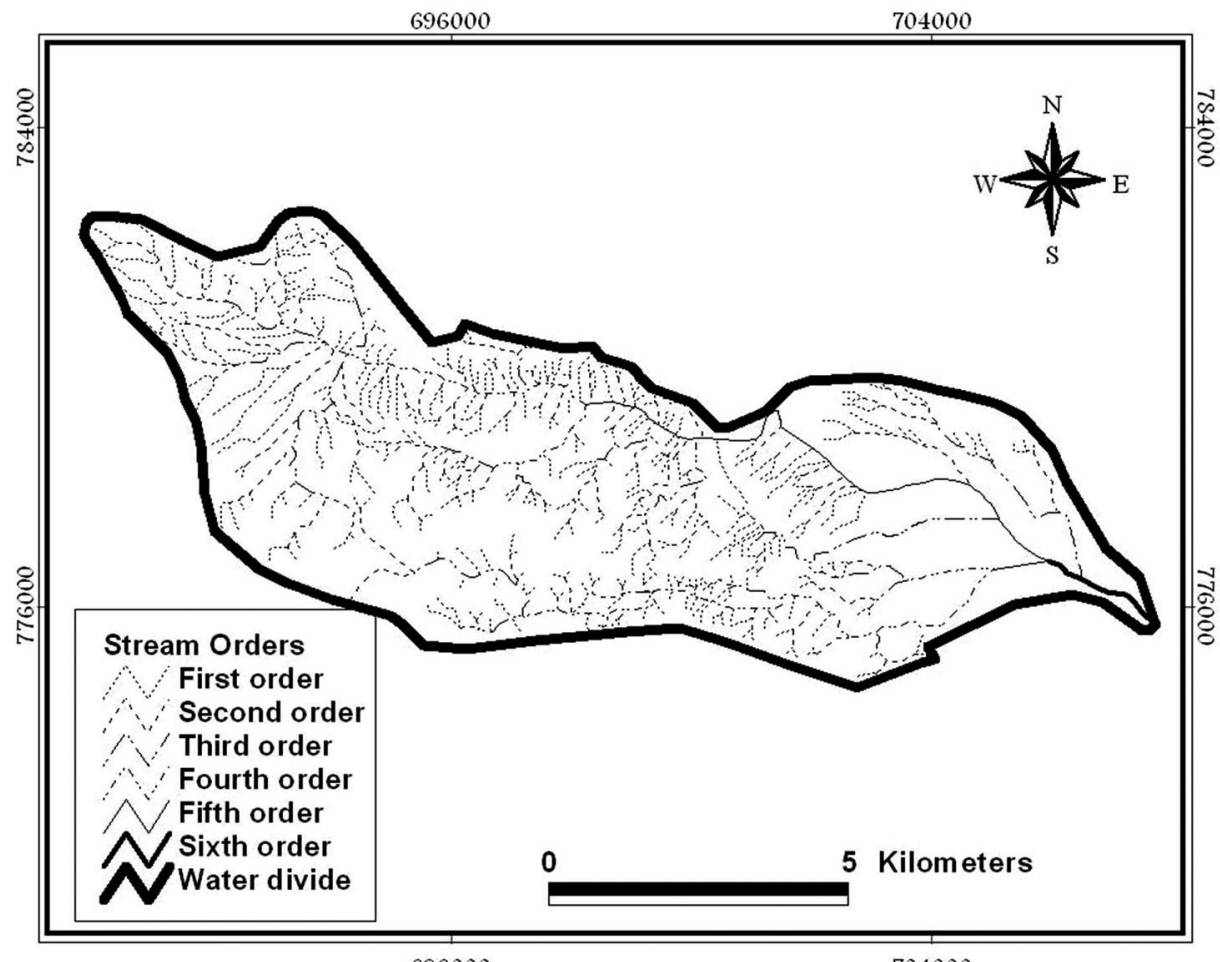

696000

704000

Fig. 8. The whole enhanced drainage networks of Wadi Umm Jirfan basin after on-screen editing and correction from underlain satellite image.

Table 2. Some morphometric parameters of Wadi Umm Jirfan derived from topographic maps of scale $(1: 50,000)$ after enhancement using satellite images.

\begin{tabular}{|c|c|c|}
\hline Order & No. of segments & Length of segments (km) \\
\hline First & 368 & 123.0 \\
\hline Second & 126 & 67.3 \\
\hline Third & 22 & 33.3 \\
\hline Fourth & 5 & 18.2 \\
\hline Fifth & 2 & 10.6 \\
\hline Sixth & 1 & 2.2 \\
\hline Bifurcation ratio & \multicolumn{2}{|c|}{3.5} \\
\hline Stream density & \multicolumn{2}{|c|}{7.5} \\
\hline Stream frequency & \multicolumn{2}{|c|}{} \\
\hline Texture ratio & \multicolumn{2}{|c|}{} \\
\hline
\end{tabular}


In watershed analysis, the decision maker depends on the interpretation of geomorphometric parameters and on surface runoff volume calculated from the drainage networks (Strahler, 1957\&1964; Morisawa, 1981 and Patton, 1988). The influence of the scale accuracy on the basin calculations would effect the basins risk assessment classification. Wrong classification may lead to consider a basin of high risk as of low-risk basin. Combining the remote sensing data in terms of satellite images with topographic maps of available scale will increase the accuracy of basin calculations and hence the confidence of their risk assessments.

El-Shamy (1992) established two relation graphs to classify the basins risk assessment based on the relations between bifurcation ratio $\left(\mathrm{R}_{\mathrm{b}}\right)$ and the drainage density (D) and the relations between bifurcation ratio versus the drainage frequency $(\mathrm{F})$. The location of any basin on the two relations designates its runoff/infiltration potentiality. Wadi Umm Jirfan basin risk assessment from topographic maps of different scales $(1: 100,000,1: 50,000$ and 1:50,000 enhanced with satellite image) are shown in Fig. 9(a-c), respectively. The dependence of morphometric parameters on the scale accuracy turned the risk of Wadi Umm Jirfan from class 'A' (high groundwater potentiality and low flooding, Fig. 9(a)) to class ' $\mathrm{C}$ ' (intermediate groundwater potentiality and flooding, Fig. 9(b)) and to class 'B' (low groundwater potentiality and high flooding, Fig. 9(c)). Smith (1950) classified the topographic texture (see $R_{t}$ in Table 3) into three categories: less than 4 as coarse-textured, from 4 to 10 as medium-textured, and more than 10 as fine-textured. It is obvious that the texture ratio of Umm Jirfan basin is turned from class to another according to the scale used in its calculation. Figure 10 shows the final enhanced drainage networks of Wadi Ghoweibba after enhancement procedure of on-screen editing and correction from the underlain satellite image.

\section{Interpretation of Morphometric Analysis of Wadi Ghoweibba}

A quick view on the drainage patterns of the study area indicate that the southern parts of the study area are characterized by the drainage lines of Wadi Naooz, Wadi El-Abyad, Wadi Diaba, Wadi El-Khafuri, and Wadi El-Khalal (Fig. 2). These are actually draining the whole top of the North Galala Plateau in northerly and northwesterly directions. The drainage lines are generally form dendritic drainage patterns (Fig. 10), where irregular nonsystematic branching of the wadies marks this type. They imply to a certain extent, that the bedrock material is essentially homogeneous and Middle Eocene limestones cap these terrains (Salem, 1988). Parallel drainage arrangement characterizes the subsequent streams draining the footslopes of the major E-W scarp of the North Galala Plateau. The western and northwestern parts, which are the high reaches of Wadi El-Shona, are characterized by subparallel to dendritic drainage pattern 


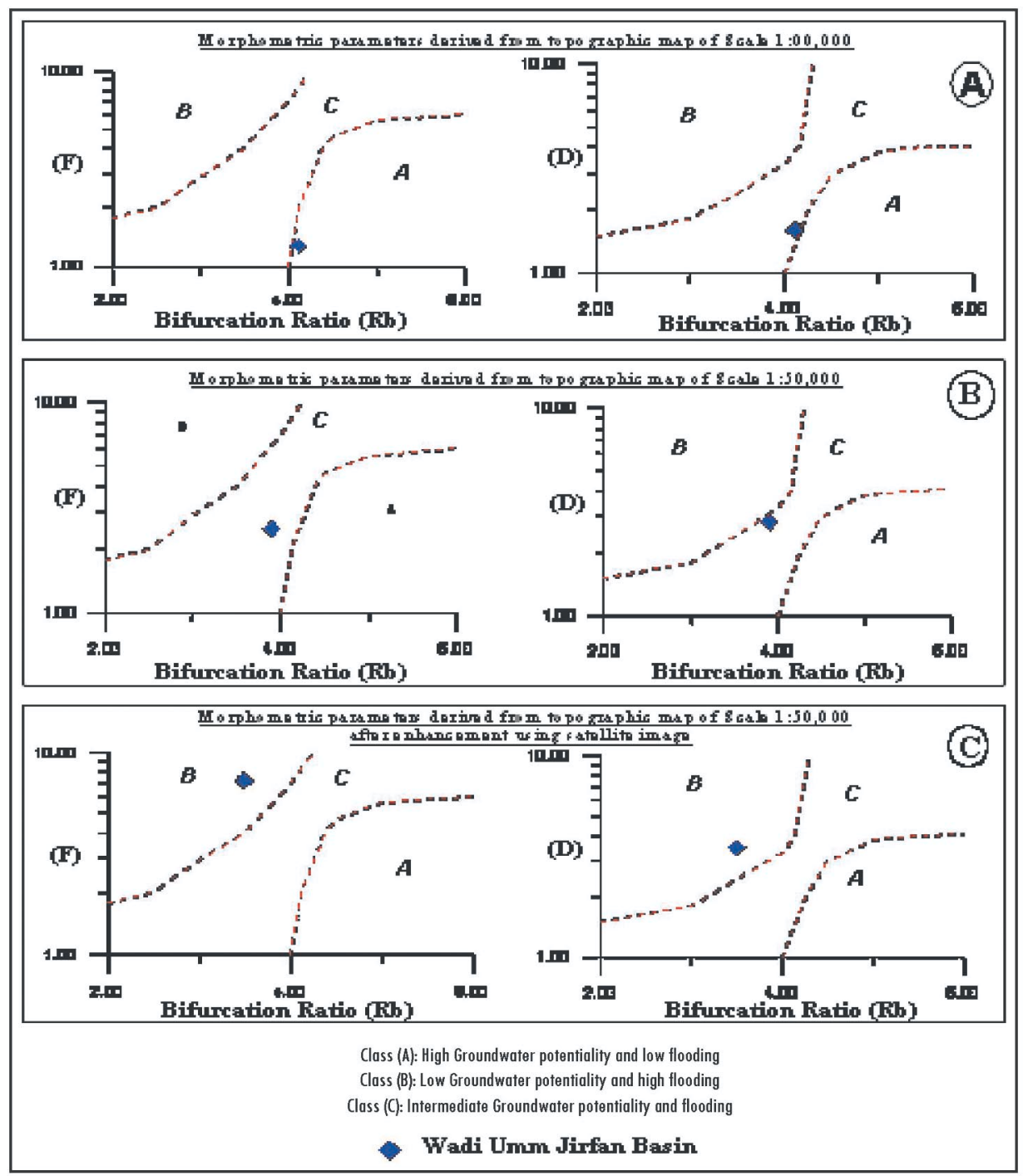

Fig. 9. Wadi Umm Jirfan basin risk assessment from topographic maps of different scales $(1: 100,000,1 ; 50,000$ and $1: 50,000$ enhanced with satellite image). 
Table 3. The equations used in morphometric parameters calculations in the present study (Shided, 2002; and others).

\begin{tabular}{|c|c|c|}
\hline Parameter name & Symbol & Equation \\
\hline Bifurcation ratio & $\mathrm{R}_{\mathrm{b}}$ & $R_{b}=N u / N u+1$ \\
\hline Drainage frequency & $\mathrm{F}$ & $\mathrm{F}=\sum_{\mathrm{i}=1}^{\mathrm{k}} \mathrm{Nu} / \mathrm{A}_{\mathrm{k}} \quad\left(\mathrm{N} / \mathrm{km}^{2}\right)$ \\
\hline Drainage density & $\mathrm{D}$ & $\mathrm{D}=\sum_{\mathrm{i}=1}^{\mathrm{k}} \mathrm{Lu} / \mathrm{A}_{\mathrm{k}} \quad\left(\mathrm{km} / \mathrm{km}^{2}\right)$ \\
\hline Constant of channel maintenance & $\mathrm{C}$ & $\mathrm{C}=1 / \mathrm{D} \quad\left(\mathrm{km}^{2} / \mathrm{km}\right)$ \\
\hline Texture ratio $\mathrm{R}_{\mathrm{t}}$ & & $\mathrm{R}_{\mathrm{t}}=\sum N_{u} / P \quad(\mathrm{~N} / \mathrm{km})$ \\
\hline Circularity ratio & $\mathrm{R}_{\mathrm{c}}$ & $\mathrm{R}_{\mathrm{c}}=4 \pi A / P^{2}$ \\
\hline Elongation ratio & $\mathrm{R}_{\mathrm{e}}$ & $\mathrm{R}_{\mathrm{e}}=\frac{2 \sqrt{A / \pi}}{\mathrm{L}}$ \\
\hline Lemniscate ratio & $\mathrm{K}$ & $\mathrm{K}=\mathrm{L}^{2} / 4 \mathrm{~A}$ \\
\hline Compactness ratio & $\mathrm{C}_{\mathrm{o}}$ & $\mathrm{C}_{\mathrm{o}}=\frac{\mathrm{P}}{2 \sqrt{A \pi}}$ \\
\hline Form factor & $\mathrm{R}_{\mathrm{f}}$ & $R_{f}=A / L^{2}$ \\
\hline $\begin{array}{c}\text { Channel gradient } \\
\left(\mathrm{L}_{\mathrm{b}}=\text { channel length in } \mathrm{m}\right)\end{array}$ & $\mathrm{S}_{\mathrm{o}}$ & $\mathrm{S}_{\mathrm{o}}=\mathrm{H}_{85 \%}-\mathrm{H}_{10 \%} / 75 \% \mathrm{~L}_{\mathrm{b}}$ \\
\hline Maximum basin relief & $\mathrm{H}_{\mathrm{m}}$ & $\begin{array}{l}\text { Elevation of basin mouth - Highest point on the } \\
\text { perimeter }\end{array}$ \\
\hline Relief ratio & $\mathrm{R}_{\mathrm{h}}$ & $\begin{array}{l}\text { The ratio of maximum basin relief to the hor- } \\
\text { izontal distance along the longest dimension of } \\
\text { the basin parallel to the principal drainage line }\end{array}$ \\
\hline Ruggedness number & $\mathrm{HD}$ & $\mathrm{HD}=\mathrm{H}_{\mathrm{m}} * \mathrm{D} / 1000$ \\
\hline Slope index & $\mathrm{S}_{\mathrm{i}}$ & $\begin{array}{l}\text { Quotient of the elevation difference between out- } \\
\text { let and basin divide (basin relief) and the main } \\
\text { channel length }\end{array}$ \\
\hline Time of concentration & $\mathrm{T}_{\mathrm{c}}$ & $\begin{array}{l}\mathrm{T}_{\mathrm{c}}=0.00032 L_{w}{ }^{0.77} S^{-0.385} \text { (S=flow velocity } \\
\text { in } \mathrm{m} / \mathrm{hr} \text { ) }\end{array}$ \\
\hline Peak of flood (Finkel, 1979) & Q & $Q=K_{1} A$ \\
\hline Volume of flood (Finkel, 1979) & $\mathrm{V}$ & $\mathrm{V}=K_{2} A$ \\
\hline Volume of runoff (Ball, 1937) & $\mathrm{V}_{\text {runoff }}$ & $\mathrm{V}_{\text {runoff }}=750 \mathrm{~A}(\mathrm{R}-8)$ \\
\hline
\end{tabular}


Table 3. Contd.

Symbols Key

\begin{tabular}{|c|c|c|c|}
\hline (A) & $=$ Basin area $\mathrm{km}^{2}$ & $(V)$ & $=$ Volume of the annual flood $\left(\mathrm{m}^{3} \times 10^{3}\right)$ \\
\hline$(P)$ & $=$ Perimeter $(\mathrm{km})$ & $(R e)$ & $=$ Elongation ratio \\
\hline$(U)$ & $=$ Stream order & $H 85 \%$ & $=$ Heights at $85 \%$ of basin length $(\mathrm{m})$ \\
\hline $\mathrm{Vu})$ & $=$ Stream number & $H 10 \%$ & $=$ Heights at $10 \%$ of basin length $(\mathrm{m})$ \\
\hline & & (So) & $=$ Channel gradient $(\mathrm{m} / \mathrm{km})$ \\
\hline$u$ & $=$ Stream length $(\mathrm{km})$ & $(H m)$ & $=$ Maximum basin relief $(m)$ \\
\hline$(R t)$ & $=$ Texture ratio $(\mathrm{N} / \mathrm{km})$ & (D) & $=$ Drainage density $\left(\mathrm{km}^{-1}\right)$ \\
\hline c) & $=$ Concentration time in hours & $(R h)$ & $=$ Relief ratio $(\mathrm{m} / \mathrm{km})$ \\
\hline$(W R b)$ & $=$ Weighted mean bifurcation ration & $(H D)$ & $=$ Ruggedness number (Dimensionless) \\
\hline$(F)$ & $=$ Drainage frequency $\left(N \cdot \mathrm{km}^{-2}\right)$ & $(R f)$ & $=$ Form factor (Dimensionless) \\
\hline (L) & $=$ Max. length $(\mathrm{km})$ & $(K)$ & $=$ Lemniscate ratio (Dimensionless) \\
\hline Co) & $=$ Compactness ratio & $(R)$ & $\begin{aligned}= & \text { Average weighted maximum rainfall } \\
& \text { in one dav }(\mathrm{mm})\end{aligned}$ \\
\hline (Rc) & $=$ Circulatory ratio & $(L w)$ & $=$ Maximum length of travel of water $(\mathrm{m})$ \\
\hline & $=$ Slope index $(\mathrm{m} / \mathrm{km})$ & $\left(K_{1} \& K_{2}\right)$ & $=$ Constants depending on the prob- \\
\hline & $=$ Constant channel maintenance $\left(\mathrm{km}^{2} / \mathrm{km}\right)$ & & ability of occurrence \\
\hline $\begin{array}{l}\left(V_{\text {runoff }}\right) \\
(Q)\end{array}$ & $\begin{array}{l}=\text { Maximum value of runoff }\left(\mathrm{M.m}^{3}\right) \\
=\text { Peak of flood flows }\left(\mathrm{m}^{3} / \mathrm{sec}\right)\end{array}$ & $(H r)$ & $\begin{aligned}= & \text { Difference in elevation between re- } \\
& \text { motest point and outlet }(\mathrm{m})\end{aligned}$ \\
\hline
\end{tabular}

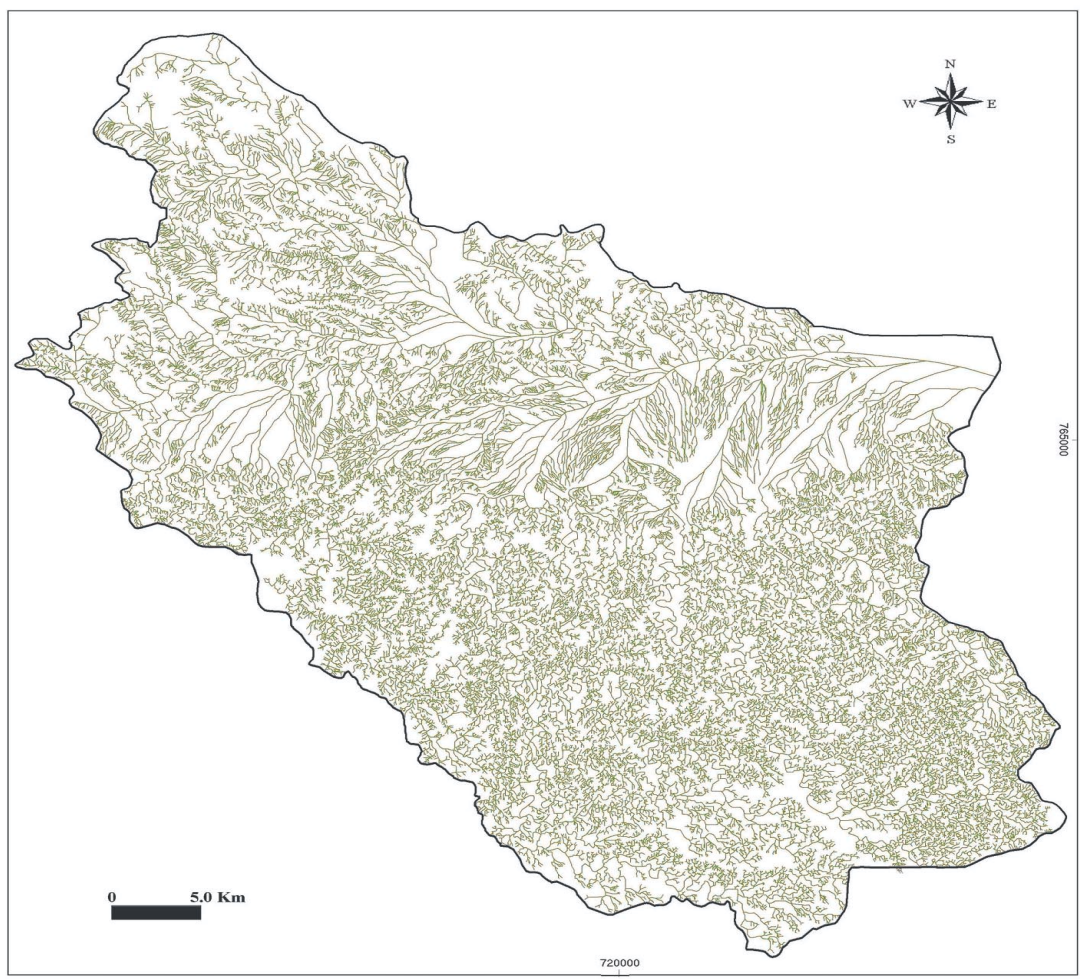

Fig. 10. The enhanced drainage networks of Wadi Ghoweibba after on-screen editing and correction from the satellite image. 
(Fig. 10). These terrains are occupied by Upper Eocene clastics. In Ghoweibba plain, the stream course becomes finely braided. This means that they are related to channel width and to depth ratios, which are functions of erodability of the stream banks.

In the present study, after applying the developed enhancement approach, the stream order of Wadi Ghoweibba basin is considered as of ninth order. This high order rank of the stream is directly proportional to the size of the contributing watershed area, the channel dimensions and to the stream discharge. Salem (1988) studied the same basin area and recorded Wadi Ghoweibba as a basin of seventh order. He used topographic maps of scale 1:100,000 to digitize the stream networks. The difference in basin orders between the present work and that of Salem (1988), as we mentioned before, is due to two factors. The first one is the scale of topographic maps used and the second one is due to the accuracy enhancement resulted from using satellite images to support the topographic maps.

Due to its large dimension Wadi Ghoweibba is divided into nine relatively large sub-basins (Fig. 11); Wadi Umm Resseiss sub-basin (No. 1), Wadi Naooz sub-basin (No. 2), Wadi El-Abyad sub-basin (No. 3), Wadi El-Khafuri-Diaba sub-basin (No. 4), Wadi El-Qena sub-basin (No. 5), Wadi Gharba-El-Shona sub-basin (No. 6), Wadi El-Sheikh-El-Ajramiya sub-basin (No. 7), and Wadi Harooz sub-basin (No. 8). The lower eastern part of Wadi Ghoweibba basin (Ghoweibba mouth) near the seashore and the small tributaries downstream directly on the main Ghoweibba trunk is considered as the ninth sub-basin. Table 3 summarizes the equations used in the calculations of morphometric parameters of all sub-basins in the study area. From the calculated morphometric and surface runoff results, we conclude the following:

- The similarities in the calculated bifurcation ratios of the nine sub-basins indicate similar genetic conditions of the stream orders for the studied subbasins. Also, the relative similarity of ranges of drainage densities for the studied sub-basins indicate that they were developed under the same climatological and hydrological conditions.

- Low values of weighted mean bifurcation ratios accompanied with the high values of both drainage frequency and density for most sub-basins give more possibilities for the occurrence of flash floods and low contribution to groundwater (Black, 1991).

- Two sub-basins (Wadi Gharba-El-Shona and Wadi El-Sheikh-El-Ajramiya sub-basins) show little degree of flash flood risk than the others. The first subbasin (Wadi Gharba-El-Shona) recorded the highest weighted mean bifurcation ratio $(\mathrm{WRb}=3.94)$ and the lowest in drainage frequency, drainage density and channel gradient values within the area $\left(\mathrm{F}=5.98 \mathrm{~N} / \mathrm{km}^{2}, \mathrm{D}=2.98 \mathrm{~km}^{-1}\right.$ and 


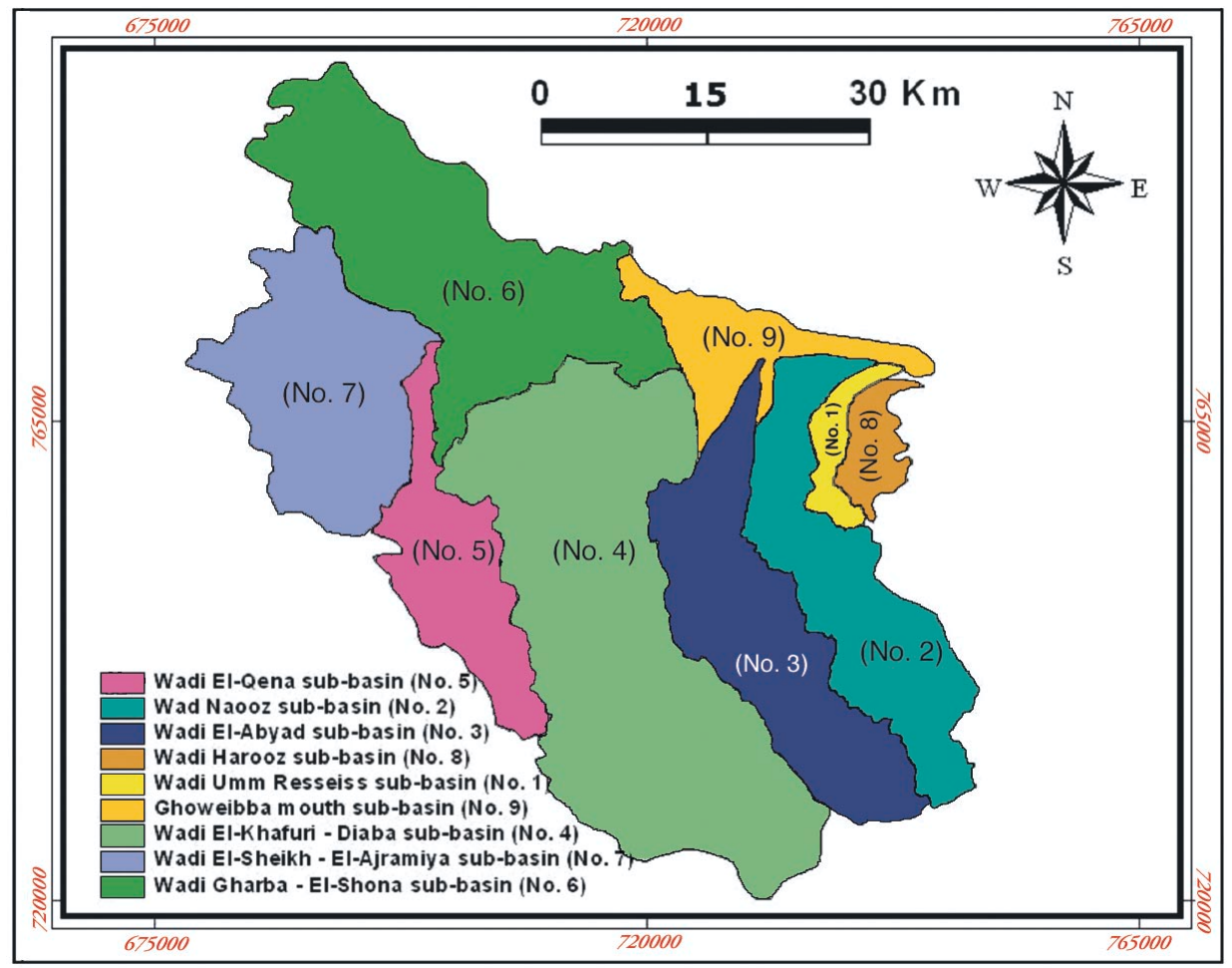

Fig. 11. Wadi Ghoweibba sub-basins.

$\mathrm{S}_{\mathrm{o}}=6.7 \mathrm{~m} / \mathrm{km}$, respectively). It also has low slope index value $\left(\mathrm{S}_{\mathrm{i}}=10.05 \mathrm{~m} / \mathrm{km}\right)$, therefore, it is classified as class ' $\mathrm{C}$ ' in El-Shamy plots (Fig. 12), which indicates an intermediate risk basin. For that sub-basin, also the constant channel maintenance value showed an increase in its permeability more than others, where the basin of high permeability subsoil minimize the flash flood potentiality and an increase in feeding the groundwater

- Although the second sub-basin (Wadi El-Sheikh and El-Ajramiya) is classified as class ' $\mathrm{B}$ ' in El-Shamy plots, it showed high value of weighted mean bifurcation ratio $\left(\mathrm{W}_{\mathrm{Rb}}=3.42\right)$ with low values of both drainage frequency and density $\left(\mathrm{F}=6.2 \mathrm{~N} / \mathrm{km}^{2}\right.$ and $\left.\mathrm{D}=3.1 \mathrm{~km}^{-1}\right)$, which minimizes the flash flood risk and increase the contribution to the groundwater potentiality. The small values of slope index $\left(\mathrm{S}_{\mathrm{i}}=10.55 \mathrm{~m} / \mathrm{km}\right)$, channel gradient $\left(\mathrm{S}_{\mathrm{o}}=9.8 \mathrm{~m} / \mathrm{km}\right)$ and basin relief $\left(\mathrm{H}_{\mathrm{m}}=480 \mathrm{~m}\right)$ indicate low intensity of erosion processes operating on the basin and hence minimizing the flash flood hazards.

- Due to the large areas of the two sub-basins $\left(562.46 \& 363.99 \mathrm{~km}^{2}\right)$, the maximum surface runoff values are expected to be high. The high subsoil infiltration rate and minimum effect of surface runoff volume could be expected 


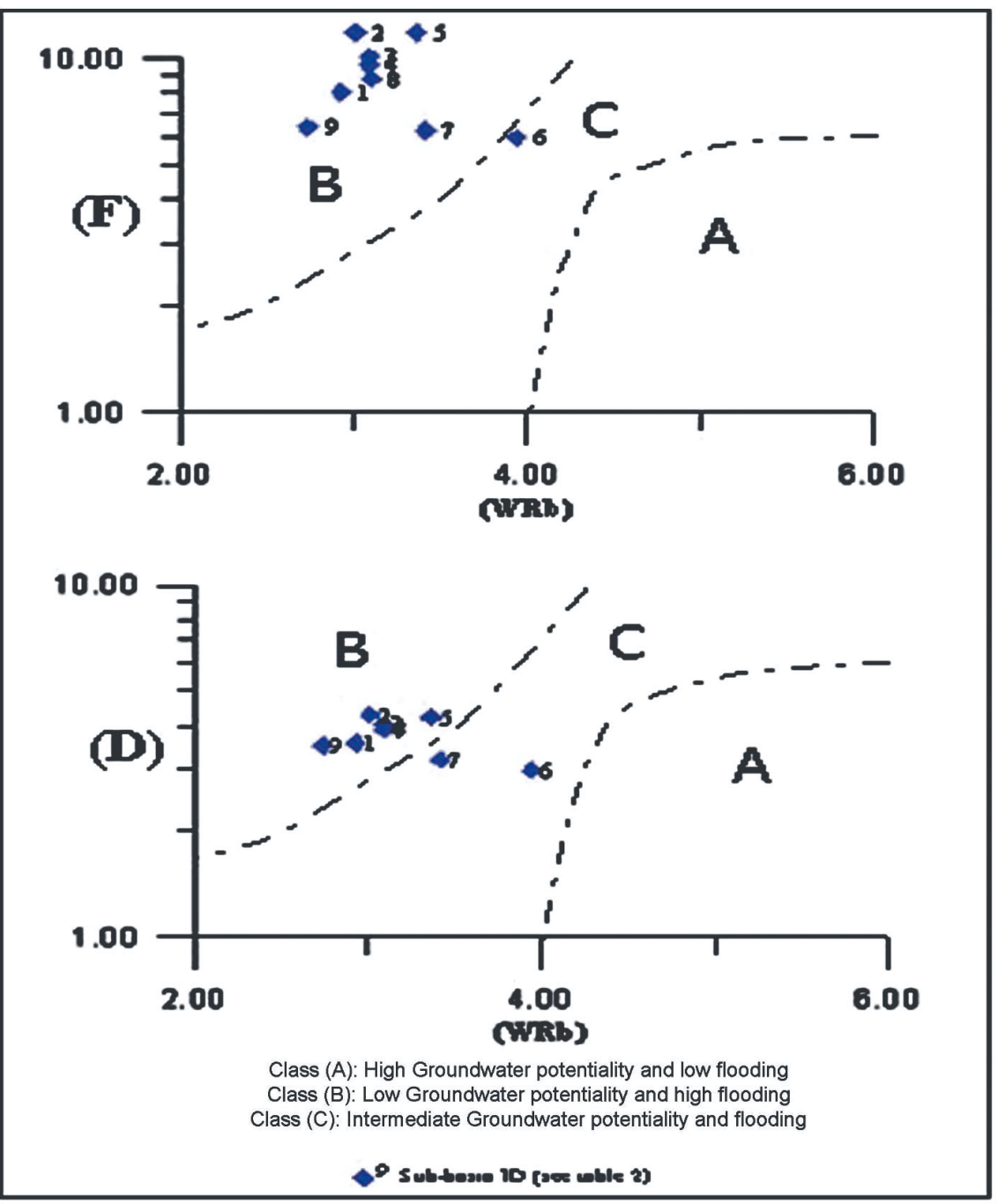

Fig. 12. Basin risk assessment according to El-Shamy (1992).

due to the increase in subsoil permeability observed according to their high constant channel maintenance values $\left(0.335 \& 0.313 \mathrm{~km}^{2} / \mathrm{km}\right)$. Existing of water barriers at these sub-basins may increase the groundwater potentiality and decrease the wasting of water during floods.

- On the other hand, the two sub-basins (Wadi Umm Resseiss and Wadi Harooz) show high degree of flash flood risk than others. They recorded high channel gradient and high relief ratio values $(>45 \mathrm{~m} / \mathrm{km})$, which may indicate, according to equation of concentration time $T_{c}$ in Table 3 and for constant stream length, that the times of runoff concentration in these two sub-basins are 
relatively short $(2.68 \& 2.38 \mathrm{~h})$ and consequently increase the flash flood potentiality. The basin relief values of these two sub-basins (914 $\mathrm{m} \& 967 \mathrm{~m}$ ) indicate the great power of the flood, where the intensity of erosion processes operating on slopes of the basin would be high. Due to the relatively small subbasins area of the two sub-basins $\left(50.17 \& 55.08 \mathrm{~km}^{2}\right)$ the recorded surface runoff values are considered the lowest within the study area.

- Although the channel gradient value in Wadi Naaoz sub-basin is less than $45 \mathrm{~m} / \mathrm{km}$, the alarm situation (i.e., high risk) in this sub-basin resulted from its large area and its maximum basin relief $\left(A=337.3 \mathrm{~km}^{2}\right.$ and $\left.\mathrm{H}_{\mathrm{m}}=1238 \mathrm{~m}\right)$. Therefore, expected value of surface runoff and the power of surface erosion would be high.

\section{Mitigation of Flash Flood Hazards}

The occasional heavy showers that take place in winter along the highland in the present time in the study area maintain short-period flash floods. The maximum-recorded precipitation during a rainstorm could reach up to $50 \mathrm{~mm}$. Torrential floods cause serious problems and cause excessive life and property losses. To prevent or at least to reduce the staging losses and problems caused by flash flood we should first outline the high-and low-risk zones. In the present study, the urban area and the oil tanks, which are lying directly on the main watercourse of Wadi Harooz outlet (Fig. 13), represent high-risk zones. The low-risk zone includes the industrial area and Ain Sukhna highway, which are lying in Wadi Ghoweibba mouth. Although this zone lying directly on the main watercourse but it is classified as low-risk zone due to the flatness present in the last ten kilometers of Wadi Ghoweibba terrain, which results in loosing the water velocity and hence minimizing the flood hazards.

The major strategy to mitigate hazards resulted from flash flood is based essentially on dispersion of flood energy by reducing runoff speed and/or diverting runoff direction by construction of flood retardation structures. These structures should take into account the simplicity, use of indigenous materials, and cost-benefit relation. Flood retardation in the study area may include the following procedures:

1. Construction of incomplete and successive rock-fill dams along the main courses of Wadi Harooz, Wadi Naooz, and Wadi Umm Resseiss. This will allow the flow to move in a zigzag way and hence decreasing its velocity.

2. Construction of synthetic dykes across the lower reaches of main wadies to prevent the runoff water from gathering in the downstream direction. Gabion stacks are suggested to construct at narrow parts of main wadies. The area lying after the conjunction of Wadi El-Shona with Wadi El-Abyad may represent a suitable region of this type of construction, where the wadi width equals $200 \mathrm{~m}$. 


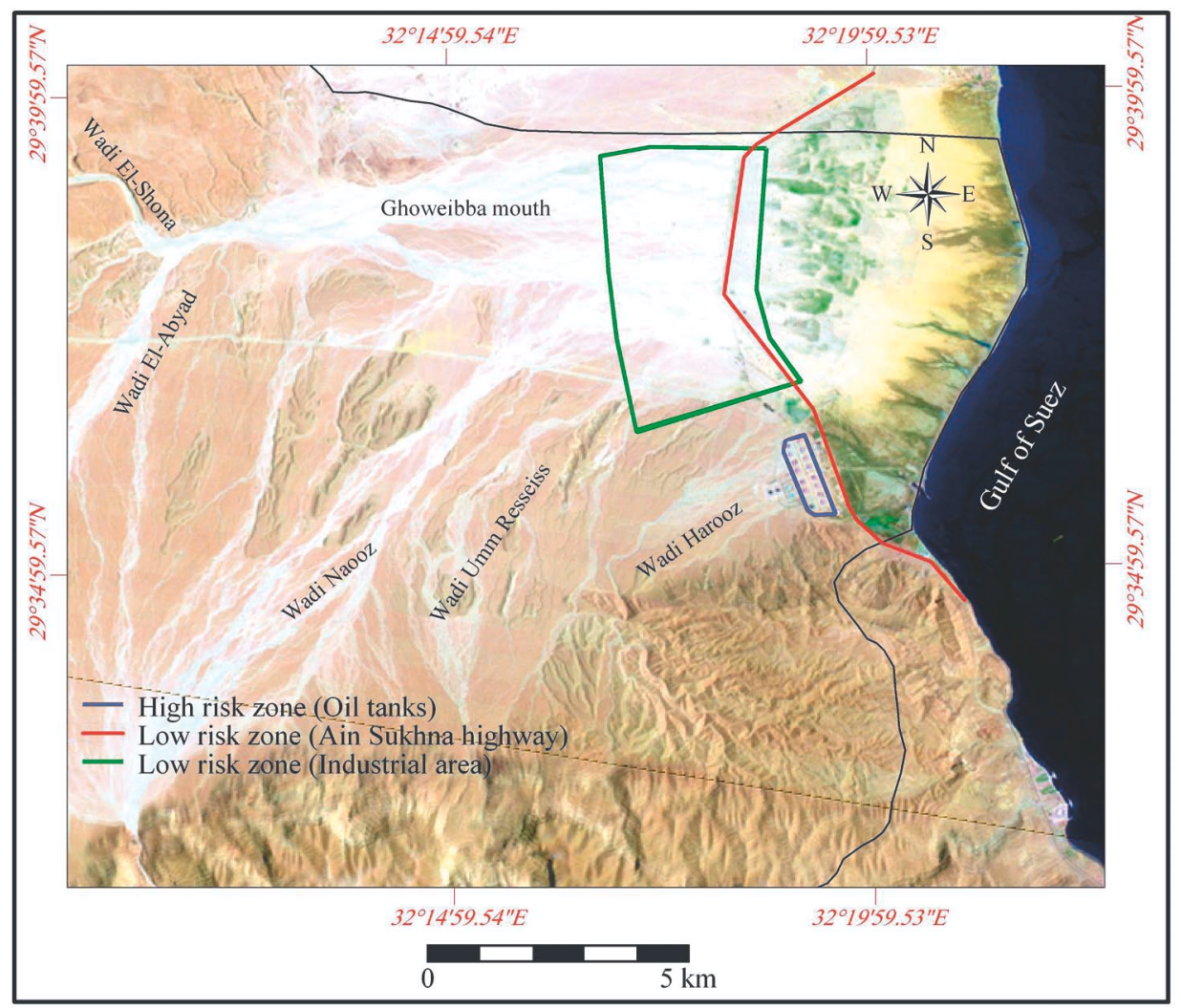

Fig. 13. Flash flood risk zones in the study area.

This would serve two goals; decreasing the flood flow to the industrial area and Ain Sukhna highway and increasing the contribution to the groundwater Quaternary aquifer, which depends essentially on rainfall recharge.

\section{Conclusion}

Quantitative description of drainage basin and drainage network, which is conventionally used to predict runoff and consequently the flash flood, is confronted with problems related to the scale and resolution of the used topographic maps and to the implemented systematic interpretation method. An approach is developed by integrating GIS and remote sensing data overlaid by large-scale topographic maps to efficiently be used to study watershed model and hence surface water potentiality. This approach is applied for quantitative analysis of geo-morphometeric parameters and to delineate watershed of Wadi Ghoweibba basin in Ain Sukhna area, western side of the Gulf of Suez, Egypt. 
The great variations in the calculated drainage density, drainage frequency and texture ratio values confirm the influence of map scale on the morphometric parameters calculations. Remote sensing data in terms of satellite images when combined with large-scale topographic maps increased the accuracy of basin calculations and hence the confidence of their risk assessments. Wrong basin risk classification may lead to consider a basin of low risk as being of high-risk basin.

The watershed model of Wadi Ghoweibba basin could be delineated for quantitative geo-morphometric analysis, which in turn is employed to delineate the flash flood risk zones and to setup effective methods of hazards mitigation. The suggested strategy to mitigate flash flood hazards is based essentially on dispersion of flood energy by reducing runoff speed and/or diverting runoff direction. This can effectively be achieved by construction of a series of flood retardation structures.

\section{References}

Abdallah, A.M.A. (1993) Structure Geology of the Area Between Ell-Gala Ell-Bavaria and Gee Okheider, Ph.D. Thesis, Fa Chi, Aim Shams Univ, Cairo, Egypt, 201 p.

Abdel Moneim, A.A., Fahim, S.M. and Ahmed, A.A. (1999) Quantitative analysis of geomorphologic characteristics and their hydrologic influence in the area southeast of Sohag, Upper Egypt, J. Geol., 43 (2): 377-394.

Ashour, M.M. and Torab, M.M. (1991) Morphometric Analysis of Basins and Drainage Networks: In Goda, H., Handbook of Morphometric Analysis, pp: 267-376.

Ball, J. (1937) Water Supply of Mersa Matruh, Survey \& Mines Dept. P.42, Cairo, 18p.

Black, P.E. (1991) Watershed Hydrology, Prentice Hall International, Advance References Series, Physical and Life Sciences, London, 319 p.

Conoco (1987) Geological Map of Egypt, Scale (1:500,000), NH 36 SW-B.S. sheet.

Drury, S.A. (1993) Image Interpretation in Geology, Chapman \& Hall, London, $2^{\text {nd }}$ ed., 211 p.

El-Fakharany, M.A. (1998) Drainage basins and flash floods management in the area southeast Qena, Eastern Desert, Egypt, Egypt. J. Geol., 42 (2): 737-750.

El-Rakaiby, M.L. (1989) Drainage basins and flash flood hazard in selected parts of Egypt, Egypt. J. Geol., 33 (1-2): 307-323.

El-Shamy, I.Z. (1992) New Approach for Hydrological Assessment of Hydrographic Basins of Recent Recharge and Flooding Possibilities, $10^{\text {th }}$ Symp. Quaternary and Development, Mansoura Univ., Egypt, p. 15.

Environmental Systems Research Institute (ESRI) (1999) GIS and Mapping Software's "Arc View-V.3.2", Redlands, California, USA.

Finkel, H.H. (1979) Water Resources in Arid Zone Settlement, A Case Study in Arid Zone Settlement, the Israeli Experience, G. Colany ed., Pergamon.

Hassaan, E.M. (1997) Geomorphology and Hydrogeology of Wadi Feiran Area and Its Surroundings, Sinai, Egypt, M.Sc Thesis, Fac. Sci., Cairo Univ., 242 p.

Morisawa, M. (1981) Quantitative Geomorphology, G. Allen \& Unwin, London, 240 p.

Patton, P.C. (1988) Drainage Basin Morphometry and Flood, In Flood Geomorphology, P. C. Pattoned, Willey Inter. Pub., pp: 51-64. 
Sabins, F.F. (2000) Remote Sensing: Principles and Interpretations, W.H. Freeman and Company, NY. USA, $188 \mathrm{p}$.

Salem, A.S. (1988) Geological and Hydrogeological Studies on the Area between Gebel Ataqa and Northern Galala Plateau, Egypt. Ph.D. Thesis, Fac. Sci., Geol. Dept., Zagazig Univ., Egypt, 271p.

Shided, A.G. (2002) Quantitative analysis of geomorphologic characteristics and their hydrologic influence in the area east Nile Delta, Egypt, $5^{\text {th }}$ Inter. Conf. Geol. Middle East Geol. Dept., Fac. Sci., Ain Shams Univ. (In press).

Smith, K.G. (1950) Standards for grading texture of erosional topography, Amer. J. Sci., 248: 655-668.

Strahler, A.N. (1957) Quantitative analyses of watershed geomorphology, Trans. Amer. Geophys. Union, 38: 913-920.

Strahler, A.N. (1964) Quantitative geomorphology of drainage basins and channel networks: in V.T. Chow (ed.) Handbook of Applied Hydrology, Section 4-II.

Stuebe, M.M. and Johnson, D.M. (1990) Runoff volume estimation using GIS technique, Water Resour. Bull., 26 (4): 611-620. 
تكامل نظم المعلو مات الجغر افية والاستشعار عن بعد لتحليل مخاطر

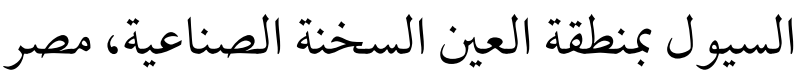

\author{
محمد جميل البحيرى، و أحمد شديد*، و أحمد عثمان أبو خضرة***، \\ و محمد الحسيني"

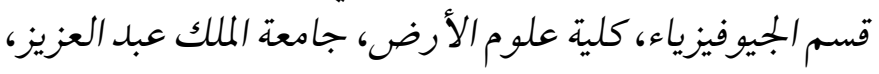

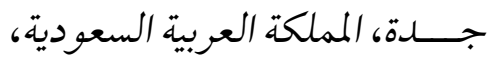

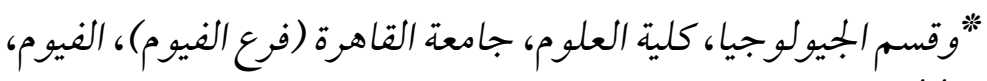

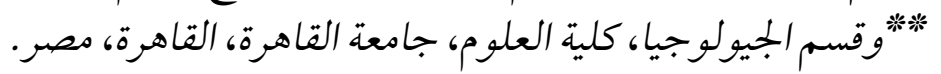

المستخلص. يعتبر تحديد شبكات صرف المياه بالوديان الرسوبية من المبات المبات

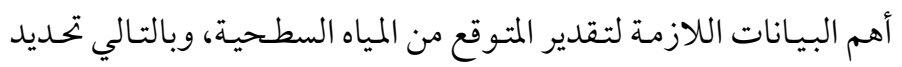

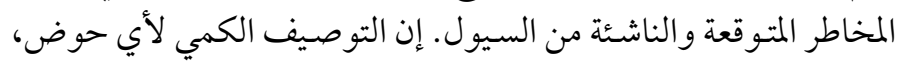

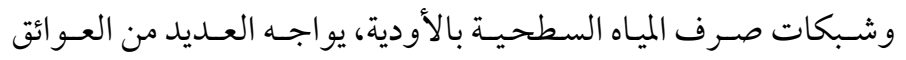

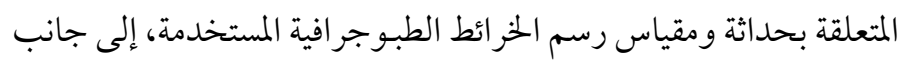
طرق التفسير التقليدي للبيانات المستخدمة.

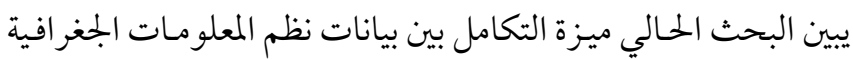

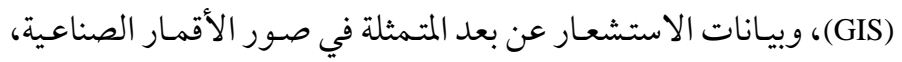

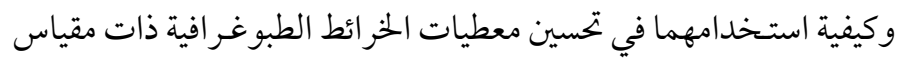

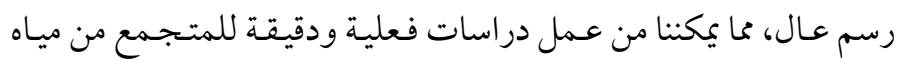
الأمطار وتقدير الكمية المخزونة من المياه السطحية.

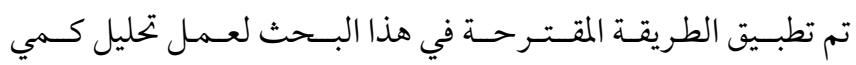

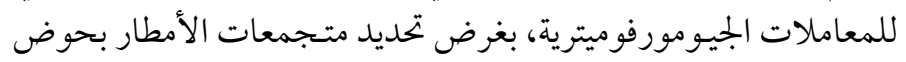

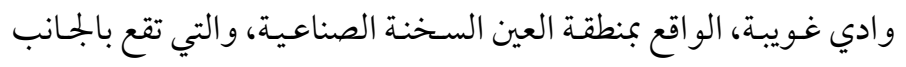

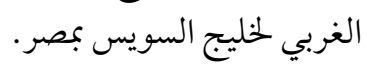

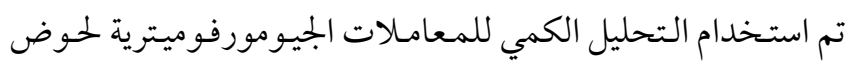

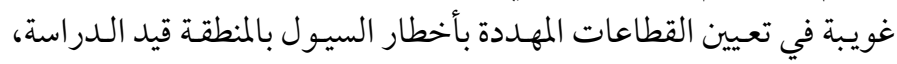

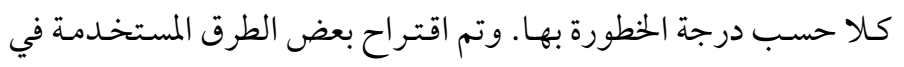
التقليل من أخطار السيول بهذه القطاعات. 